DOI: 10.2478/RAE-2019-0023 Review of Artistic Education no. 182019 212-218

NUMBER 18 / PART III

FINE ARTS

\title{
1. THE EVOLUTION OF HABITAT IN MIDDLE HALLSTATT ON THE TERRITORY OF ROMANIA
}

Ioana-Iulia Olaru ${ }^{210}$

\begin{abstract}
The paper will refer only to one of period of Hallstatt, Middle Hallstatt, an important period of the first Iron Age - that form with Late Hallstatt a unity called by historian the protohistory of the Dacians - bringing important transformations recorded in the human beings' habitat. The settlements and buildings of the entire Bronze Age reflect the continuation of migrations, though limited, by their sedentarization, but also the fortification of some settlements which became real centres of unions of tribes. The characteristic to the mentioned period is continuity (and then the ending) of the process of unification of the Thracian tribes, a process began in Early Hallstatt. The collision of tribes needed the amplification of settlements, but also of the fortifications and also, step by step, the extending of the Greek urbanism implemented in today's Dobrogea by the Greeks who started colonies here, the Scythian-Greek incluences are to be found in the Late Hallstatt and in other areas on the nowadays territory of our country. The specificity of settlements and buildings of the cultures from the beginning of Hallstatt on the territory of our country will be studied in their evolution towards the next phase - of the second period of the Iron Age: Latène.
\end{abstract}

Key words: ash pit, tumulus, agora, bastion, krepidoma, cella, emplecton

\section{About the Metal Age}

Composed of the Bronze Age and the Iron Age, the Metal Age is the period during which the first signs of a new state-urban revolution appeared, and stone tools are replaced by the ones made of metal (this process dates back to the end of Eneolithic). Even before the middle period of the Bronze Age, the Carpathian-Danubian space has become one of the important metallurgical centers of Europe.

\section{Generalities about the Iron Age}

A new moment of impetuous development regarding production forces came once the other metal started spreading - iron, which was more practical than bronze; iron metallurgy was discovered by the Hittites and they brought it on the territory of today's Romania. During the entire Iron Age ${ }^{211}$, agriculture becomes

\footnotetext{
210 Associate Professor PhD., "George Enescu" National University of Arts from Iaşi, Romania, email: olaru.ioana.iulia@gmail.com

211 Approximately 1 150/1 000 - 50/70 B.C.: the date of constituting the Dacian State. Cf. Dinu C. Giurescu, Istoria ilustrată a românilor, București, Ed. Sport-Turism, 1981, p.25; Constantin C. Giurescu, Dinu C. Giurescu, Istoria românilor din cele mai vechi timpuri şi pînă astăzi, Bucureşti, Ed. Albatros, 1971, p.30; Vasile
} 
more and more intense (through the generalization of the usage of iron tools and of the plough with an iron ploughshare), but shepherdess is now a basic occupation generating wealth. Still, step by step, given the limitation of migration, people partially returned to sedentarization, but the infiltration of Eastern groups will continue during the entire Iron Age. Craftsmen occupy a special place in society; merchants appeared, given the more intensive exchange of goods. The society continued to become more and more divided and differentiated in distinctive classes. The consolidation of tribe unions will lead to bigger conflicts.

\section{The Settlements of the Irona Age}

In this period, the number of settlements increases, the ones that were strengthened became true centres of tribes of tribe unions - among which relationships become more intense. This is the way outstanding fortresses were built, centres defended by waves (having a structure made of logs and stone), with high palissade above them and deep ditches in front of them: Sântana Arad, Mediaş, Teleac (Transylvania); Stânceşti (Botoşani), Cotnari (Iaşi County), Buneşti - Avereşti (Vaslui County) (Moldavia); Satu Nou (Dobrogea); Albeşti (Muntenia); Verbicioara (Oltenia).

\section{The First pPriod of the Iron Age}

In the first period of the Iron $\mathrm{Age}^{212}$, Hallstatt ${ }^{213}$, the identity of the Northern-Pontical tribes was crystallized; now, the proto-Thracians separated in North-Danubian Geto-Dacian (what is specific to them is the ceramic culture decorated with cannelures) and South-Danubian Thracians (recognized for their cultures with printed ceramics, in the Thracian meridional group). New features are added to the old aspects of Bronze spirituality: the perpetuation of the solar cult, the diminishing of the number of necropoleis, the simultaneous practice of inhumation and incineration, but in the Late Hallstatt, incineration will be step by step extended (and later, in Latène, this ritual became fundamental) ${ }^{214}$.

Another feature of this period is represented by an aesthetic side which is not very much present in art, but we should signal the fact that the Scythians brought in small art (which was not very much developed) the zoomorphic style: animals represented in a naturalistic way, while moving or in complicated

\footnotetext{
Pârvan, Getica. O protoistorie a Daciei, București, Ed. Meridiane, 1982, p.174; H. D., in Radu Florescu, Hadrian Daicoviciu, Lucian Roşu (coord.), Dicţionar enciclopedic de artă veche a României, Bucureşti, Ed. Ştiinţifică şi Enciclopedică, 1980, p.155, s.v. fierului, epoca

212 Approximately 1 150/800 - 450/300 B.C. Cf. A. Vulpe, M. Petrescu-Dîmbovița, A. Lászlo, Cap.III. Epoca metalelor, in Mircea Petrescu-Dîmboviţa, Alexandru Vulpe (coord.), Istoria românilor, vol.I, Moștenirea timpurilor indepărtate, Bucureşti, Academia Română, Ed. Enciclopedică, 2010, p.289; H. D., in Radu Florescu et al. (coord.), op. cit., p.155, s.v. fierului, epoca

${ }^{213}$ Up to the year 800 B.C., there was a period which is confounded with the end of the Bronze Age. Cf. H. D., in Radu Florescu et al. (coord.), op. cit., p.155, s.v. fierului, epoca

${ }^{214}$ Constantin Buzdugan, Riturile funerare ale comunităților hallstattiene târzii din Moldova, in Acta Moldaviae Meridionalis, II, 1980, Vaslui, p.51
} 
attitudes. Composing together what the specialists have called the Protohistory of the Dacians, the middle period and the late period of Hallstatt brought changes to be found also in the habitat plan.

\section{The Cultures of the Meddle Period of Hallstatt}

Indo-European populations from the northern branch came over the Danube in the middle period of Hallstatt $(\mathrm{Ha} \mathrm{C})^{215}$, from the proto-Thracian later appeared the Geto-Dacian tribes ${ }^{216}$, from the middle part of Iron Age, the unification process of Thracian tribes was over on the territory of our country and the unitarian Geto-Dacian population was formed, this population will have a slow evolution influenced by the Celtic Central Europe, the Hellenistic South, also having some oriental influentions. It is a wealthy period. Funeral habits are not known everywhere: there were discovered graves that were isolated from incineration (Iernut, Chendul Mare, Mureș County, Blejești, Teleorman County, Ciurelu - Bucharest, Izvoru Dulce, Buzău County, Matca, Galați County), incineration necropoleis (Dăliște), tumuli (Bujoru) and inhumation graves (Şoldănești, on the Dnestr), inhumation necropoleis (Basarabi) ${ }^{217}$.

In parallel with the slow evolution of the Geto-Dacians, on the nowadays territory of Dobrogea, a colonial Greek society started to develop and it entered in the history of Antiquity, having a civilizing influence over the limitrophe Getic society (Dobrogea, the South and the centre of Moldavia, the East of Muntenia). The Greeks have had the biggest and most complex influence over the Dacians, through the forms of Greek-Roman traditions, taken over and integrated in the local tradition, and also through the Greek fortresses that have formed the urban centres of the Dacian world.

In the biggest part of the territory of Romania, the great cultural synthesis was developed: the cultural complex Basarabi (named after the eponym place from Dolj County), extended also in the North of Bulgaria and in the North of the former Jugoslavia ${ }^{218}$, appeared on the local Hallstattian basis (the resemblance with the cultures of Bronze Age: Tei, Gârla Mare, Wietenberg are not a mere coincidence); it was found in Banat, Vojvodina, Serbia, Oltenia, Câmpia Română, the South of Moldavia (up to the Dnestr), Mureș basin, the shore of the Danube, from Novi Sad up to Dobrogea and between the Balcans and the Danube. This cultural complex already represents the individualization of the Geto-Dacians in the Thracian branch ${ }^{219}$. On Dobrogea's territory, this is

\footnotetext{
215 Approximately 850/800 - 650 B.C. Cf. A. Vulpe et al., op. cit., p.294

${ }^{216}$ The chronological order of the appearance of these notions in ancient sources would suppose the usage of the name Geto-Dacian (not Dacian-Gets). Ibidem, p.433

${ }^{217}$ Ibidem, p.334

${ }^{218}$ Dinu C. Giurescu, op. cit., p. 25

219 Liviu Marghitan, Considerații referitoare la geneza și evoluția societății dace pe meleaguri bănățene, in Ziridava, XII, 1980, Arad, p.79
} 
the period during which the first settlements appeared ${ }^{220}$, on the shore of the Black Sea, the Greek collonialists have found here a civilisation typical for Hallstatt $\mathrm{C}^{221}$.

\section{The Settlements of the Middle Period of Hallstatt}

The fights between the tribes led to the strengthening of fortification systems; great fortified settlements, having ditches and waves of clay and logs appeared. In Basarabi culture, open settlements continued to exist, being like a dwelling and there were also great fortresses made of clay (Remetea-Pogănici, Caraș-Severin County, Hunedoara, Popești, Giurgiu County, Poiana, Galați County, Teleac, Alba County, Bernadea, Mureș County) - fortified settlements (except for Bernada), with ditches and palisades and clay waves (the ones that have been studied, from Remetea - Pogănici and from Popești having a core of burnt clay against erosion) $)^{222}$, also having ash pits, hovels, surface settlements, probably made of wood $^{223}$.

On the territory of Dobrogea, from the $7^{\text {th }}$ century B.C. date the first sure settlements of the Greek presence on the shore of the Black Sea: the oldest colony being the one from Istros (Histria) (Istria village, Constanța County). It became an important commercial centre in the $6^{\text {th }}$ century B.C. (its importance diminished towards the middle of the $3^{\text {rd }}$ century B.C., once the Celts invaded Lower Danube) ) $^{224}$. When Istros was founded (if not even earlier, according to the latest research ${ }^{225}$ : the middle of the $7^{\text {th }}$ century B.C. $\left.{ }^{226}\right)$, Orgame also appeared (Argamum) (Capul Dolojman, Jurilovca, Tulcea County) and, because of the fact that there were no monuments found in this period, the initial image can't be rebuilt. Just a small portion of the wall from the classic and Hellenistic period was found (with assises of figured blocks of limestone, the foundation of a bulwark being clinging), and also a few settlements, having reduced dimensions (one having a lot of rooms, among which one was a sanctuary), with walls made of limestone small blocks that were bound with clay, daubted with argil, the roof being made of tile painted in $\operatorname{red}^{227}$. Here was found the oldest Greek tomb from Dobrogea, in a tumular necropolis (the middle of the $7^{\text {th }}$

\footnotetext{
${ }^{220}$ Apoikiai - commercial cities for the exchange with the local Geto-Dacian population. Cf. Ion Miclea, Dobrogea, București, Ed. Sport-Turism, 1978, p.27

${ }^{221}$ A. Avram, Gh. Poenaru Bordea, Cap.VII. Coloniile grecești din Dobrogea, in Mircea Petrescu-Dîmboviţa, Alexandru Vulpe (coord.), op. cit., p.563

${ }^{222}$ A. Vulpe et al., op. cit., p.330

${ }^{223}$ Ion Miclea, Radu Florescu, Preistoria Daciei, București, Ed. Meridiane, 1980, p.124

${ }^{224}$ Vasile Pârvan, Dacia. Civilizațiile antice din țările carpato-danubiene, București, Ed. științifică, 1972, p.87, 89

${ }^{225}$ Mihaela Mănucu-Adameşteanu, Orgame/Argamum, Tulcea, ICEM, 2001, p.23

${ }^{226}$ Ibidem, p. 11

${ }^{227}$ Ibidem, p.40-48
} 
century B.C. ${ }^{228}$ ). Probably ${ }^{229}$ in the second half of the 6th century B.C. ${ }^{230}$, Tomis colony was created in Constanța, the Ionian or Greeks founded it, they also came from Milet (whose role started to become more and more important from the 3rd century B.C. ${ }^{231}$ ), and in the last two decades of the $6^{\text {th }}$ century B.C., the Dorian Fortress Callatis (Mangalia) was built, made by the greeks that came from the Pontic Heraclee ${ }^{232}$ (that became important in the 4th century B.C.) ${ }^{233}$.

Anyway, what is characteristic to all these cities-fortresses is the Greek urbanism that was implemented here, known from what could have been identified in the case of Hystria city: it was organized according to a street network having an orthogonal network; this ordonnance became complicated, after the building of the last wall of the enclosure, by juxtaposing another orthogonal grid, parallel with the line of the enclosure wall. The old wall of Hystria, dating from the Hellenistic period, was built respecting the rules of the Greek technique, from stone blocks splintered off in regular shapes, with two paraments and emplecton made of soil with stone rocks, rebuild afterwards on several occasions; it was situated at $90 \mathrm{~m}$ from the big wall from the Roman epoch. It had towers and a gate with baffle $e^{234}$. The sacred area of the great Greek walls, put on the acropolis, in the North-Eastern part of the fortress ${ }^{235}$, is dated from the $5^{\text {th }}$ century - the $3^{\text {rd }}$ century B.C. The temple dedicated to Zeus Polieus, on a stone foundation ${ }^{236}$, with a krepidoma having 4 steps, had a narthex and a cella surrounded by a wood colonnade ${ }^{237}$. Another temple, made of marble, in a Doric style, dating from the $3^{\text {rd }}$ century B.C., is dedicated to the Great God (a Thracian deity full of mystery); there are marble fragments of a Doric column, fronton, trigliphs, metopes, architrave ${ }^{238}$. A small temple dedicated to Aphrodites, from the same century, had a square nave, a narthex, probably a peristyle, what was left from the temple was only the inferior part (krepis) ${ }^{239}$. As far as the rest in concerned, there are simple houses (but built on river bed foundations: these are foundations made of clay layers which alternate with those of ashes), and also tumular necropoleis of incineration, beyond the

\footnotetext{
${ }^{228}$ A. Vulpe, Cap.V. Istoria și civilizația spațiului carpato-dunărean între mijlocul secolului al VII-lea și inceputul secolului al III-lea a.Chr., in Mircea Petrescu-Dîmboviţa, Alexandru Vulpe (coord.), op. cit., p.482; Mihaela Mănucu-Adameşteanu, op. cit., p.14

229 The founding data are known only for Hystria and Callatis. Cf. Ion Miclea, Radu Florescu, Geto-dacii. Strămoșii românilor. Vestigii milenare de cultură și artă, București, Ed. Meridiane, 1980, p.30

${ }^{230}$ V. Canarache, Tomis, București, Ed. Meridiane, 1961, p.9

${ }^{231}$ Vasile Pârvan, Dacia... p.86-87

232 Constantin Preda, Callatis, București, Ed. Meridiane, 1968, p.7

${ }^{233}$ Vasile Pârvan, Dacia..., p.86-87

${ }^{234}$ Ion Miclea, Radu Florescu, Geto-dacii.., p.33

${ }^{235}$ Ibidem

${ }^{236}$ Radu Florescu, Ion Miclea, Histria, București, Ed. Sport-Turism, 1989, p.18

${ }^{237}$ Ibidem

${ }^{238}$ Paul MacKendrick, Pietrele dacilor vorbesc, București, Ed. Științifică și Enciclopedică, 1978, p.29

${ }^{239}$ Em. Condurachi, Histria, București, Ed. Meridiane, 1968, p.15-32
} 
lakes $^{240}$. There were agorasin Istros and in Tomis (there are inscriptions which represent a proof in this respect), with porticos and edifices unidentified on the field, but known through the discovered pieces (architraves, friezes, capitals) ${ }^{241}$. A hippodamic ordonnance was remarked in the city of Callatis ${ }^{242}$, where tracks of the defence wall from the $4^{\text {th }}$ century B.C. were preserved (made of limestone blocks and having uncarved stones inside of it, mixed with clay ${ }^{243}$. Unfortunately, in the case of Tomis, the overlapping of Roman and RomanByzantine buildings makes architectural remains be rare. Still, around the old building of the museum, Greek walls were discovered, being dated in the $7^{\text {th }}$ century - the $4^{\text {th }}$ century B.C. ${ }^{244}$.

In this period, the rite of incineration became generalized - in tumular and plain cemeteries. There were found inhumation necropoleis (they are proofs of the Illyric penetration) (Balta Verde, Gogoșu, Basarabi), and also of incineration which are autochthonous (Blejești, Balta Verde) ${ }^{245}$, this rite imposed itself.

\section{Conclusions}

The establishment of settlement that started in Hallstatt A-B, given the development of the society regarding all aspects, being in agreement with the calming down of the migrations, will later lead to tribal unification. This fact meant settlements fortified with ditches and clay and stone waves; regarding religious buildings, even a complex cult was supposed to belong to Babadag culture. In the middle period, this process will continue, at the middle period of the Iron Age, the unification process of the Thracian tribes on the territory of our country was over and so was the formation of the unitary Geto-Dacian population. Thus, we have seen how the great cultural synthesis took place, the complex from Basarabi, what the individualization of the Geto-Dacians represents inside the Thracian people, being accompanied by an unseen development of the society in today's Dobrogea, where the Greek colonists set the basis of an urbanism which will be step by step extended, also involving the extra-Carpathian areas.

\section{References}

\section{BOOKS}

1. Canarache, V., Tomis, București, Ed. Meridiane, 1961

2. Condurachi, Em., Histria, București, Ed. Meridiane, 1968

\footnotetext{
${ }^{240}$ Ion Miclea, Radu Florescu, Geto-dacii..., p.33

${ }^{241}$ A. Avram et al., op. cit., p.617

${ }^{242}$ R. F., in Radu Florescu et al. (coord.), op. cit., p.351, s.v. urbanism

${ }^{243}$ Constantin Preda, op. cit., p.20

${ }^{244}$ Mihai Gramatopol, Dacia antiqua. Perspective de istoria artei și teoria culturii, București, Ed. Albatros, 1982 , p.32

${ }^{245}$ Ion Miclea, Radu Florescu, Preistoria Daciei, p.124
} 
3. Florescu, Radu, Daicoviciu, Hadrian, Roşu, Lucian (coord.), Dicţionar enciclopedic de artă veche a României, București, Ed. Ştiinţifică şi Enciclopedică, 1980

4. Florescu, Radu, Ion Miclea, Histria, București, Ed. Sport-Turism, 1989

5. Giurescu, Constantin C., Giurescu, Dinu C., Istoria românilor din cele mai vechi timpuri şi pînă astăzi, Bucureşti, Ed. Albatros, 1971

6. Giurescu, Dinu C., Istoria ilustrată a românilor, București, Ed. Sport-Turism, 1981

7. Gramatopol, Mihai, Dacia antiqua. Perspective de istoria artei și teoria culturii, București, Ed. Albatros, 1982

8. MacKendrick, Paul, Pietrele dacilor vorbesc, București, Ed. Științifică și Enciclopedică, 1978

9. Mănucu-Adameşteanu, Mihaela, Orgame/Argamum, Tulcea, ICEM, 2001

10. Miclea, Ion, Dobrogea, București, Ed. Sport-Turism, 1978

11. Miclea, Ion, Florescu, Radu, Geto-dacii. Strămoșii românilor. Vestigii milenare de cultură și artă, București, Ed. Meridiane, 1980

12. Miclea, Ion, Florescu, Radu, Preistoria Daciei, București, Ed. Meridiane, 1980

13. Pârvan, Vasile, Dacia. Civilizațiile antice din țările carpato-danubiene, București, Ed. științifică, 1972

14. Pârvan, Vasile, Getica. O protoistorie a Daciei, București, Ed. Meridiane, 1982

15. Petrescu-Dîmboviţa, Mircea, Vulpe, Alexandru (coord.), Istoria românilor, vol.I, Moştenirea timpurilor îndepărtate, Bucureşti, Academia Română, Ed. Enciclopedică, 2010

16. Preda, Constantin, Callatis, București, Ed. Meridiane, 1968

\section{ARTICLES}

1. Buzdugan, Constantin, Riturile funerare ale comunităților hallstattiene târzii din Moldova, in Acta Moldaviae Meridionalis, II, 1980, Vaslui, p.51-60

2. Marghitan, Liviu, Considerații referitoare la geneza și evoluția societății dace pe meleaguri bănățene, in Ziridava, XII, 1980, Arad, p.71-84 